\title{
Postgraduate Symposium
}

\section{Dietary and genetic modulation of DNA repair in healthy human adults}

\author{
J. Tyson* and J. C. Mathers \\ Human Nutrition Research Centre, School of Clinical Medical Sciences, Framlington Place, Newcastle University, \\ Newcastle upon Tyne NE2 4HH, UK
}

\begin{abstract}
The DNA in all cells of the human body is subject to damage continuously from exogenous agents, internal cellular processes and spontaneous decomposition. Failure to repair such damage is fundamental to the development of many diseases and to ageing. Fortunately, the vast majority of DNA damage is detected and repaired by one of five complementary DNA repair systems. However, recent studies have shown that even in healthy individuals there is a wide inter-individual variation in DNA repair capacity. Part of this variation can be accounted for by polymorphisms in the genes encoding DNA repair proteins. However, it is probable that environmental factors, including dietary exposure as well as diet-gene interactions, are also responsible for much of the difference in repair capacity between individuals. Whilst there is some evidence from human studies that generalised malnutrition or low intakes of specific nutrients may affect DNA repair, as yet there is limited understanding of the molecular mechanisms through which nutrients can modulate this key cellular process.
\end{abstract}

DNA repair systems: Polymorphisms: Diet-gene interactions

DNA is constantly subject to damage arising either spontaneously or from a plethora of endogenous and exogenous agents. Such DNA damage, if unrepaired, leads to aberrant gene expression and is fundamental to the initiation and development of cancer, with additional implications for ageing and a wide range of diseases including diabetes, vascular disease and dementia. Although DNA damage arises frequently, with $2 \times 10^{5}$ damaging events occurring per cell per $24 \mathrm{~h}$, mutation is rare, with only one in $10^{10}$ nucleotides becoming mutated per cell generation (Jackson $\&$ Loeb, 2001). This low incidence of mutation is largely a result of the ability of cells to perform an array of evolutionarily-conserved DNA repair mechanisms that maintain the integrity of the genome. Human cells have five complementary DNA repair systems, encoded by $>150$ genes and protein products. Each system detects and repairs specific types of DNA damage (see Table 1). The five human DNA repair systems are: direct reversal; mismatch repair; base excision repair (BER); double-strand break repair; nucleotide excision repair (NER).

\section{DNA repair systems \\ Direct reversal}

Direct reversal involves the direct removal of damage adducts from the DNA rather than entire damaged nucleotides. Although direct reversal systems are common in prokaryotic systems, in man only one such system exists. Alkylation of guanine at the $\mathrm{O}^{6}$ position results in an $\mathrm{O}^{6}$-alkylguanine lesion, which is capable of pairing with thymine and, if left unrepaired, results in a $\mathrm{G} \rightarrow \mathrm{A}$ transition mutation post replication. In human subjects $\mathrm{O}^{6}$-alkylguanine can be repaired by $\mathrm{O}^{6}$-methylguanine-DNA methyltransferase, which transfers the alkyl group to a cysteine residue within the protein, restoring the damaged guanine to its correct form.

\section{Mismatch repair}

Mismatch repair serves to repair a number of common mutagenic lesions. Misincorporation (mispairing) of bases

\footnotetext{
Abbreviations: BER, base excision repair; ERCC1, excision repair cross-complementing rodent repair deficiency complementation group 1; NER, nucleotide excision repair; SNP, single-nucleotide polymorphism; XP, xeroderma pigmentosum; XPA, XPB, XPC, XPD, XPF, XPG, XP complementation groups $\mathrm{A}, \mathrm{B}, \mathrm{C}, \mathrm{D}, \mathrm{F}$ and $\mathrm{G}$ respectively.

*Corresponding author: John Tyson, fax +44 191222 8684, email john.tyson@ncl.ac.uk
} 
Table 1. Summary of human DNA repair mechanisms

\begin{tabular}{|c|c|c|}
\hline Repair pathway & Damage repaired & Sources of damage \\
\hline Mismatch repair & Mismatched base pairs, small insertion loops & $\begin{array}{l}\text { Replication errors, minor base modifications (oxidation, } \\
\text { alkylation) }\end{array}$ \\
\hline Base excision repair & $\begin{array}{l}\text { Oxidised bases alkylation, abasic/AP sites, } \\
\text { single-strand breaks }\end{array}$ & $\begin{array}{l}\text { Reactive oxygen species, alkylating agents, spontaneous } \\
\text { hydrolysis }\end{array}$ \\
\hline Nucleotide excision repair & Bulky helix-distorting lesions & $\begin{array}{l}\text { UV light, cigarette smoke, dietary factors (aflatoxin, PhiP, } \\
\text { polyaromatic hydrocarbons(benzo[ } \alpha] \text { pyrine)) }\end{array}$ \\
\hline Double-strand break repair & Double-strand breaks, DNA cross-links & $\begin{array}{l}\text { Ionising radiation, cross-linking agents (cisplatin), } \\
\text { replication errors }\end{array}$ \\
\hline Direct reversal & Alkylated bases: $0^{6}$-methyl-guanine & Alkylating agents, nitrosoureas, streptozotocin \\
\hline
\end{tabular}

PhiP, 2-amino-1-methyl-6-phenylimidazo [4,5- $\beta]$ pyridine; AP, apurinic/apyrimidinic.

(e.g. T/C or A/G), caused by errors in DNA replication as well as alkyl adducts, and oxidatively-damaged bases are repaired by mismatch repair. One such mismatch lesion that is commonly found arises from the deamination of cytosines to uracil or methylated cytosines to thymine, which if unrepaired cause a $\mathrm{C} \rightarrow \mathrm{T}$ transversion post DNA replication. Mismatch repair also serves to repair small insertions and deletions in the DNA caused when the DNA polymerase 'slips', usually in repetitive microsatellite DNA sequences.

The process of mismatch repair involves twenty-six genes and proteins and their encoded proteins that act in three stages to remove and repair damage. First, the mismatched base is recognised by the MSH2/MSH6 heterodimer. The damaged strand around the lesion is unwound and removed, involving the MLH1/PMS2 heterodimer and other proteins. This stage leaves a single-stranded gap, which is repaired by specific polymerases and DNA ligase 1 (Jiricny \& Nystrom-Lahti, 2000).

\section{Double-strand break repair}

Double-strand breaks are the most cytotoxic and potentially mutagenic lesions that can afflict DNA, as they can quickly lead to chromosomal breaks or exchanges and cell death. Double-strand breaks are induced by ionising radiation, mechanical stress and calastogens (agents causing visible chromosomal damage) such as the chemotherapeutic agent cisplatin (Pfeiffer et al. 2000). Repair of double-strand breaks may proceed through two distinct pathways: the error-free homologous recombination; the error-prone non-homologous end joining, which is crude in that it simply ligates the two ends of a double-strand break (Christmann et al. 2003). Homologous recombination uses the homology of the sister chromatid to facilitate high-fidelity repair of double-strand breaks. Homologous recombination begins with the digestion of one strand of DNA at the break site, resulting in a single-stranded $3^{\prime}$ overhang (Christmann et al. 2003). The RAD52 and RAD51 proteins promote the formation of nucleofilaments and facilitate interactions between the damaged strand and the undamaged DNA on the sister chromosome. Thereafter, strand exchange takes place, allowing the synthesis of new DNA across the break using the undamaged chromosome as a template.

\section{Base excision repair}

BER is responsible for the repair of numerous small mutagenic lesions that do not disrupt the DNA double helix. The most-frequently-repaired lesions are apurinic/ apryimidinic sites, in which the base is missing from the DNA backbone (Seeberg et al. 1995). Base deamination, oxidation and alkylation, which can cause mispairing and lead to mutations post replication are also repaired through the BER pathway. BER can be divided into three stages: damage is recognised; damaged bases are removed creating an apurinic/apryimidinic site; apurinic/apryimidinic sites are filled with the synthesis of new DNA. In human subjects there are eleven glycosylases that are able to recognise damaged bases and cleave them from the sugar phosphate backbone, creating an apurinic/apryimidinic site (Hung et al. 2005). For repair to continue apurinic/ apryimidinic sites must be incised to create a single-strand break, either by the glycosylase itself or by the apurinic/ apryimidinic endonuclease enzyme. Such sites (created spontaneously, by glycosylases or by apurinic/apryimidinic endonuclease) are repaired in one of two ways: (1) shortpatch repair, in which a single nucleotide in inserted into the apurinic/apryimidinic site by DNA polymerase $\beta$ and DNA ligase; (2) long-patch repair, in which an additional two to thirteen nucleotides are removed and the gap repaired by polymerases and ligase (Christmann et al. 2003).

\section{Nucleotide excision repair}

NER is a complex DNA repair pathway involving over thirty genes and proteins (Friedberg, 2001) and is responsible for the repair of any DNA lesion that causes distortion to the DNA double helix. NER commonly repairs lesions induced by $\mathrm{UV}$ as well as numerous exogenous agents such as those derived from food and smoking, including 2-amino-1-methyl-6-phenylimidazo [4,5- $\beta]$ pyridine and benzo[ $\alpha]$ pyrene diol-epoxide.

NER can be divided into two distinct pathways: global genomic repair; transcription-coupled repair. Transcription-coupled repair repairs lesions that block the progression of RNA polymerase along actively-transcribed genes. Global genomic repair is independent of transcription and acts to repair lesions in non-transcribed regions of the genome as well as those in the non-transcribed strand of 


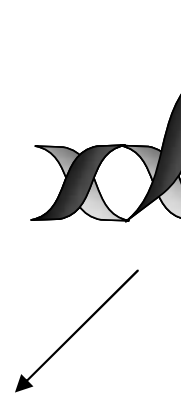

Damage recognition
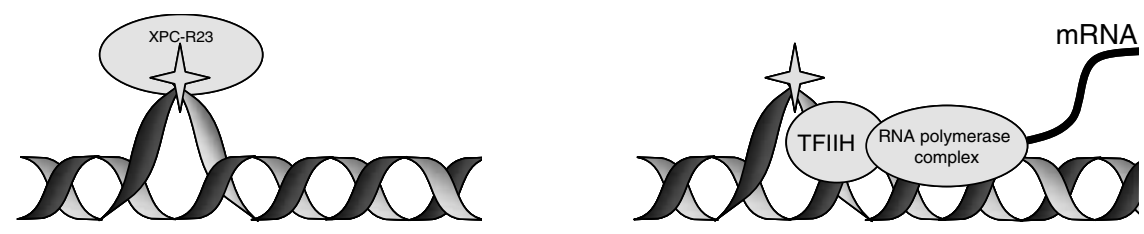

Two pathways converge
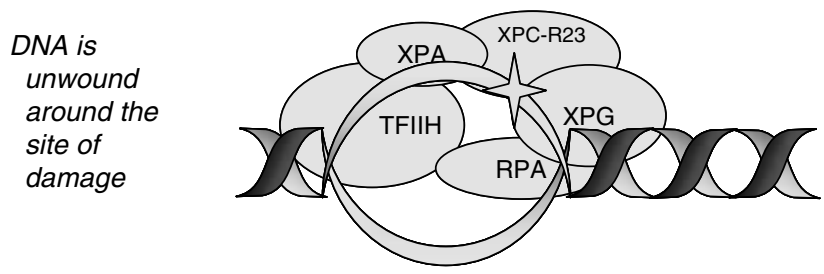

\section{Damage strand is incised}

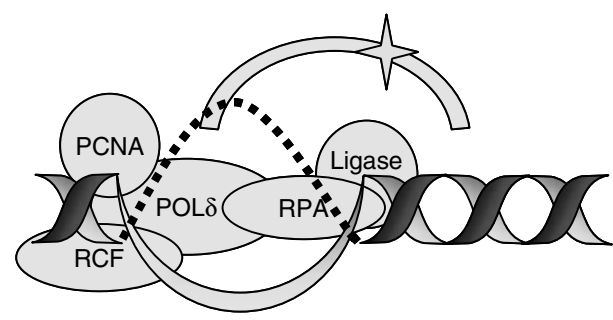

Repaired DNA

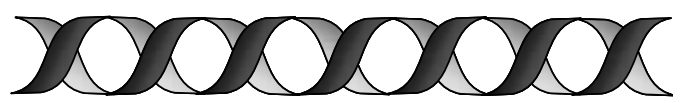

Fig. 1. Overview of nucleotide excision repair pathway. XPA, XPC, XPG, xeroderma pigmentosum complementation groups $A, C$ and $G$; TFIIH, transcription factor $11 \mathrm{H}$; RPA, replication protein $A$; PCNA, proliferating cell nuclear antigen; RCF, replication factor $C$; POL $\delta$, DNA polymerase $\delta$. (Adapted from Friedberg, 2001.)

active genes. These two pathways differ only in the way DNA damage is detected, with the subsequent repair steps being identical (see Fig. 1).

In transcription-coupled repair a helix-distorting lesion located in an actively-transcribed gene halts the progression of the RNA polymerase at the site of damage. The stalling of the polymerase initiates the removal and repair of the damage, allowing transcription to continue. In global genomic repair the xeroderma pigmentosum (XP) complementation group C (XPC) protein, in association with UV excision repair protein RAD23 homologue B, recognises and binds to the helix distortion caused by the damage rather than to the lesion itself. The initiation of transcription-coupled repair is faster than the initiation of global genomic repair, presumably because of the implications of DNA damage during mRNA synthesis (Benhamou \& Sarasin, 2000).

Once the site of damage has been recognised, DNA is unwound around the lesion by two helicase enzymes XPB (unwinding $3^{\prime}$ to $5^{\prime}$ ) and XPD (unwinding $5^{\prime}$ to $3^{\prime}$ ). Both 
Table 2. Summary of genetic syndromes characterised by a defect in DNA repair

\begin{tabular}{|c|c|c|}
\hline Disease & $\begin{array}{l}\text { Type of genetic } \\
\text { disorder }\end{array}$ & $\begin{array}{c}\text { DNA repair } \\
\text { system disrupted }\end{array}$ \\
\hline Ataxia telangiectasia & Autosomal recessive & Strand break repair \\
\hline Nijmegen breakage syndrome & Autosomal recessive & Strand break repair \\
\hline Bloom's syndrome & Autosomal recessive & Strand break repair* \\
\hline Werner syndrome & Autosomal recessive & Strand break repair \\
\hline Rothman-Thomson syndrome & Autosomal recessive & Strand break repair* \\
\hline Fanconi anaemia & Autosomal recessive & Strand break repair* \\
\hline Hereditary non-polyposis colo-rectal cancer & Autosomal dominant & Mismatch repair \\
\hline Xeroderma pigmentosa & Autosomal recessive & Nucleotide excision repair \\
\hline Trichothiodystrophy & Autosomal recessive & Nucleotide excision repair \\
\hline Cockayne syndrome & Autosomal recessive & $\begin{array}{l}\text { Transcription-coupled nucleotide } \\
\text { excision repair }\end{array}$ \\
\hline
\end{tabular}

*May be disruption to more than one repair pathway.

XPD and XPB are part of the basal transcription factor IIH complex, which is essential for the initiation of transcription by RNA polymerase II. This unwinding creates distinct junctions between double-stranded and singlestranded DNA, which are essential for the progression of repair (Friedberg, 2001). The damaged strand of DNA is incised at these two junctions, i.e. at the $3^{\prime}$ side of the damage by XPG protein and at the $5^{\prime}$ side by the XPFexcision repair cross-complementing rodent repair deficiency complementation group 1 (ERCC1) complex. This step results in cleavage and subsequent removal of approximately thirty nucleotides of single-stranded DNA containing the damage. The remaining single-stranded gap is filled by DNA polymerase $\delta$ or $\varepsilon$ and the new strand is joined to the existing DNA by DNA ligase (de Laat et al. 1999).

\section{Inter-individual variation in DNA repair capacity and disease}

Loss, or severe impairment, of DNA repair processes results in a decrease in the ability to process DNA damage and ultimately leads to disease, most often cancer. A number of familial syndromes arise as a result of a disruption to DNA repair processes (summarised in Table 2). One such disorder is XP, which is a rare autosomal recessive syndrome characterised by a severe photosensitivity of sunlight-exposed areas of the skin from an early age. Patients with XP have inactivating mutations in any one of seven genes encoding proteins essential for NER, have $\leq 1000$-fold increased risk of skin malignancies and are also ten to twenty times more likely to develop internal tumours at $<20$ years of age (de Boer \& Hoeijmakers, 2000).

Fortunately, such heritable syndromes, resulting in a complete disruption to DNA repair processes, are rare and account for only a small proportion of cancer incidence. However, large inter-individual variations in DNA repair capacity have been observed in healthy populations. Qiao et al. (2002a) have found a 4.7-fold variation in NER capacity, measured using the host cell reactivation assay, in 102 healthy subjects (Qiao et al. 2002a). Also, DNA repair of UV-induced damage, measured using the unscheduled DNA synthesis assay varies over an approximately 8-fold range, again in healthy control subjects (Mohankumar et al. 1998). Amongst sixty-three young (mean age 21 years) healthy volunteers recruited to the Dietary Antioxidant Repair Trial there is a 10-fold inter-individual variation in NER capacity, measured using the host cell reactivation assay (see Fig. 2; Tyson et al. 2005).

Inter-individual variation in DNA repair capacity within the general population is believed to be associated with cancer risk. Case-control studies have shown that cancer patients have a repair capacity below that of healthy matched controls. For example, reduced NER capacity has been associated with increased risk of cancer of the skin, lung, head and neck, and breast (Ana et al. 2005). Additionally, there may be links between recombinational repair and sporadic breast cancer (Ralhan et al. 2006) and a reduced BER capacity may also increase risk of lung cancer (Paz-Elizur et al. 2003). In a review of studies carried out before 1998 it has been concluded that there is a consistent positive correlation between reduced DNA repair capacity and cancer occurrence, with OR of between 1.4 and $75 \cdot 3$ (Berwick \& Vineis, 2000). However, as yet no prospective studies have been conducted and a reduced DNA repair capacity could be a result of, rather than a cause of, cancer.

The possible reasons for the substantial inter-individual variation in DNA repair capacity may include genetic factors, such as polymorphisms in DNA repair genes, and variation in environmental exposure, including dietary and lifestyle factors. For example, variation in DNA repair is partly attributable to variations in age and BMI, both of which are inversely associated with NER capacity (Tyson et al. 2006).

\section{Genetic polymorphisms, DNA repair and cancer risk}

Common genetic polymorphisms in DNA repair genes have been associated with the inter-individual variation in DNA repair and also with cancer risk. The majority of genes encoding proteins important in DNA repair are polymorphic (Mohrenweiser et al. 2002). For example, there are a number of polymorphisms in the ERCC2 gene 


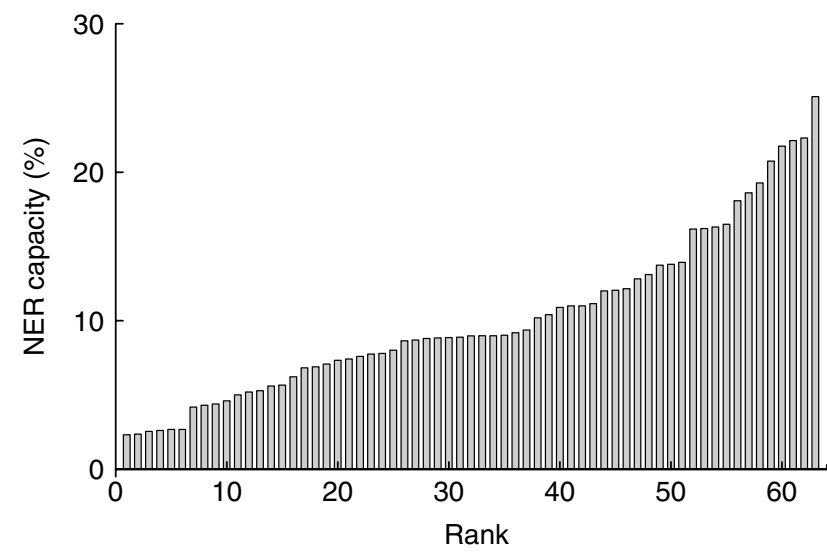

Fig. 2. Inter-individual variation in nucleotide excision repair capacity, measured using the host cell reactivation assay, in sixty-three healthy volunteers recruited to the Diet and Reinfarction Trial (Tyson et al. 2005).

that encodes for the XPD protein, a DNA helicase essential for NER. The ERCC2 Asp312Asn single-nucleotide polymorphism (SNP) has a modulatory effect on both NER capacity and adduct levels, with carriers of one or more of the Asn alleles showing reduced repair capacity (Spitz et al. 2001) and increased adduct levels (Hou et al. 2002; Tang et al. 2002) compared with homozygotes of the Asp allele. In addition, the Gln allele of the ERCC2 Lys751Gln SNP has been associated with both reduced NER capacity (Spitz et al. 2001; Qiao et al. 2002b) and increased prevalence of adducts (Palli et al. 2001; Hou et al. 2002; Tang et al. 2002). Similar effects are seen in other repair systems, with variants of the BER proteins 8-oxoguanine DNA glycosylase 1 and X-ray cross-complementing group 1 showing reduced activity (Pachkowski et al. 2006; Sokhansanj \& Wilson, 2006).

The same polymorphisms that appear to modulate repair capacity have been associated with cancer risk. Again, polymorphisms of the ERCC2 gene are implicated, with carriers of the uncommon alleles being found in greater frequencies amongst groups of cancer sufferers than amongst controls (Benhamou \& Sarasin, 2005). Also, polymorphisms in BER genes are often found to convey increased cancer risk (Hung et al. 2005). A meta-analysis of BER polymorphisms and cancer risk (Hung et al. 2005) has shown that Cys/Cys homozygotes for the 8-oxoguanine DNA glycosylase 1 Ser326Cys polymorphism have an increased risk of lung cancer (OR 1.24) and the carriers of the Trp allele of the X-ray cross-complementing group 1 194Trp SNP are protected against tobacco-related cancers.

However, such genetic associations with repair capacity and with cancer risk are not observed consistently. For example, in contrast to the other findings the ERCC2 Lys751Gln SNP has been reported to have no effect on NER capacity (Qiao et al. 2002b), adduct levels (Duell et al. 2000) or cancer risk (Benhamou \& Sarasin, 2005). This lack of reproducibility in genetic-association studies is common and may arise for a number of reasons. Differential findings may be related to differences in study size and statistical power, with large studies having greater power to detect smaller effects. Alternatively, the interactions between genetic and environmental factors could be important, with the effect of genotype being apparent only in certain environmental settings. Finally, polymorphisms believed to affect repair capacity and cancer may be in linkage disequilibrium with neighbouring polymorphisms in the same or adjacent genes.

The effect of multiple polymorphisms in NER genes on NER repair capacity has been investigated. In the Dietary Antioxidant Repair Trial (Tyson et al. 2006) NER capacity was measured in sixty-three subjects who had been genotyped for polymorphisms in key NER genes. Here, two significant gene-gene interactions were found when subjects were grouped according to genotype for each polymorphism based on the presence or absence of the uncommon allele. The XPC Lys939Gln SNP appears to interact with both the ERCC5 Asp1104His and the ERCC2 Lys751Gnl SNP $(P=0.01$ and $P=0.03$ respectively), with repair capacity being dependent on specific allelic combinations of the polymorphisms. In the case of ERCC5 Asp1104His SNP repair capacity appears to be independent of the Asp allele, whereas carriers of the His allele show high repair in the absence of the Gln allele of the $X P C$ Lys939Gln SNP and low repair in the presence of this SNP. In the case of the ERCC2 Lys751Gnl SNP repair capacity is independent of the presence the Gln allele, but homozygotes of the Lys allele have a high repair capacity in the absence of the Gln allele of the Lys751Gnl SNP and low repair capacity in the presence of this SNP.

\section{Nutritional modulation of DNA repair}

There is a clear link between diet and cancer, with variation in diet accounting for over one-third of the variation in cancer incidence (Doll \& Peto, 1981). Epidemiological evidence shows convincingly that diets rich in fruit and vegetables are associated with a decreased risk of cancer of the lung, mouth, pharynx, oesophagus, colon and rectum (World Cancer Research Fund/American Institute for Cancer Research, 1997). There are also probable risk reductions for laryngeal, pancreatic, breast and bladder cancers associated with such diets (World Cancer Research Fund/American Institute for Cancer Research, 1997). More recently, the European Prospective Investigation into Cancer and Nutrition Study has shown that diets low in fibre (Bingham et al. 2003) and/or high in red meat are associated with an increased risk of colo-rectal cancer (Gonzalez et al. 2002; Norat et al. 2005). Much effort has been put into defining the dietary constituents and the biological mechanisms underlying the protective effects of diet on cancer. Many studies (see Moller \& Loft, 2004) have investigated the effects of dietary components on levels of DNA damage. However, DNA damage is only of consequence if it cannot be adequately repaired, so that the individual's ability to perform DNA repair may be at least as important as the damage they sustain.

To date a relatively small number of studies (summarised in Table 3) have investigated the influence of diet or nutrient status on DNA repair processes. Perhaps not 
Table 3. Summary of studies investigating dietary modulation of DNA repair

\begin{tabular}{|c|c|c|c|c|}
\hline Reference & Study design & $\begin{array}{l}\text { DNA repair } \\
\text { measurement }\end{array}$ & Subjects & Main outcomes \\
\hline $\begin{array}{l}\text { Moller \& Loft } \\
\quad(2004)\end{array}$ & $\begin{array}{l}\text { Blinded placebo-controlled } \\
\text { intervention. Three treatment } \\
\text { groups: (1) slow release } \\
\text { vitamin } \mathrm{C}+\text { vitamin } \mathrm{E} ;(2) \text { plain } \\
\text { release vitamin } \mathrm{C}+\text { vitamin } \mathrm{E} ; \\
\text { (3) placebo. Treated for } \\
4 \text { weeks }\end{array}$ & OGG1 mRNA levels & $\begin{array}{l}\text { Forty-eight male } \\
\text { smokers (20-65 } \\
\text { years) }\end{array}$ & $\begin{array}{l}\text { No effect of intervention on } \\
\text { OGG1 expression }\end{array}$ \\
\hline $\begin{array}{l}\text { Moller et al. } \\
\quad(2003)\end{array}$ & $\begin{array}{l}\text { Intervention study. Parallel design } \\
\text { with subjects treated for } 24 \mathrm{~d} \\
\text { with: (1) } 600 \mathrm{~g} \text { fruit and } \\
\text { vegetables; (2) tablets } \\
\text { providing 'same' amount of } \\
\text { antioxidants and minerals; } \\
\text { (3) placebo }\end{array}$ & $\begin{array}{l}\text { OGG1 and ERCC1 } \\
\text { mRNA levels }\end{array}$ & $\begin{array}{l}\text { Forty-three subjects } \\
\text { (twenty-one female) } \\
\text { aged } 21-56 \text { years }\end{array}$ & $\begin{array}{l}\text { No effect of intervention on } \\
\text { OGG1 or ERCC1 } \\
\text { expression }\end{array}$ \\
\hline $\begin{array}{l}\text { Collins et al. } \\
\text { (2003) }\end{array}$ & $\begin{array}{l}\text { Randomised cross-over } \\
\text { intervention study. Subjects } \\
\text { supplemented with one, two } \\
\text { and three kiwi fruit for } 3 \text { weeks } \\
\text { with 2-week wash-out periods } \\
\text { between treatments }\end{array}$ & $\begin{array}{l}\text { BER capacity using a } \\
\text { modified comet assay } \\
\text { and OGG1 and APE1 } \\
\text { mRNA levels }\end{array}$ & $\begin{array}{l}\text { Fourteen (eight female) } \\
\text { healthy non-smokers } \\
\text { aged } 26-54 \text { years }\end{array}$ & $\begin{array}{l}\text { Increase in BER capacity after } \\
\text { supplementation, } \\
\text { independent of no. of kiwi } \\
\text { consumed. No change in } \\
\text { OGG1 or APE1 expression }\end{array}$ \\
\hline $\begin{array}{l}\text { Tomasetti et al. } \\
\text { (2001) }\end{array}$ & $\begin{array}{l}\text { Intervention study. Subjects took } \\
100 \mathrm{mg} \text { ubiquinine-10 for } \\
1 \text { week }\end{array}$ & $\begin{array}{l}\text { BER capacity using a } \\
\text { modified comet assay }\end{array}$ & $\begin{array}{l}\text { Six healthy non- } \\
\text { smokers (three } \\
\text { female) aged } 26-54 \\
\text { years }\end{array}$ & $\begin{array}{l}\text { Significant }(P<0.05) 2 \cdot 7 \text {-fold } \\
\text { increase in repair capacity } \\
\text { after supplementation }\end{array}$ \\
\hline $\begin{array}{l}\text { Astley et al. } \\
\text { (2004) }\end{array}$ & $\begin{array}{l}\text { Intervention study. Subjects } \\
\text { assigned to treatment group } \\
\text { and asked to take one of the } \\
\text { following for } 3 \text { weeks: (1) } 200 \mathrm{~g} \\
\text { cooked minced carrots; } \\
\text { (2) total of } 11.9 \mathrm{mg} \alpha \text { - and } \\
\beta \text {-carotene }+1.75 \mathrm{mg} \\
\alpha \text {-tocopherol; (3) } 298 \mathrm{~g} \text { tinned } \\
\text { mandarins, } 60 \text { mg vitamin C; } \\
\text { (4) placebo capsules }\end{array}$ & $\begin{array}{l}\text { The repair of single- } \\
\text { strand breaks and } \\
\text { oxidative lesions was } \\
\text { measured using a } \\
\text { patch synthesis assay }\end{array}$ & $\begin{array}{l}\text { Sixty-four healthy male } \\
\text { subjects aged } 18-50 \\
\text { years }\end{array}$ & $\begin{array}{l}\text { Repair capacity increased } \\
\text { significantly }(P<0.05) \text { only } \\
\text { after treatment } 1 \\
\text { (supplementation with the } \\
\text { cooked minced carrots). No } \\
\text { effect of treatments } 2,3 \text { or } 4\end{array}$ \\
\hline $\begin{array}{l}\text { Sheng et al. } \\
\text { (1998) }\end{array}$ & $\begin{array}{l}\text { Intervention study. Subjects } \\
\text { supplemented with a } \\
\text { combination of nicotinamide, } \\
\text { Zn and carotenoids for } 7 \text { weeks }\end{array}$ & $\begin{array}{l}\text { Followed repair of } \mathrm{H}_{2} \mathrm{O}_{2-} \\
\text { induced DNA damage } \\
\text { over time using the } \\
\text { comet assay }\end{array}$ & Four healthy volunteers & $\begin{array}{l}\text { Significant increase in repair } \\
\text { seen }(P<0 \cdot 01) \text { post } \\
\text { supplementation }\end{array}$ \\
\hline $\begin{array}{l}\text { Chiricolo et al. } \\
\text { (1993) }\end{array}$ & $\begin{array}{l}\text { Intervention study. Children with } \\
\text { Down syndrome (DS) and } \\
\text { healthy controls were given } \\
1 \mathrm{mg} \mathrm{Zn/kg} \mathrm{body} \mathrm{weight} \mathrm{for} \\
4 \text { months }\end{array}$ & $\begin{array}{l}\text { Repair of } \gamma \text {-radiation } \\
\text { followed using alkali } \\
\text { elution assay }\end{array}$ & $\begin{array}{l}\text { Fifteen children in each } \\
\text { treatment group, } \\
\text { mean age } 9 \text { years }\end{array}$ & $\begin{array}{l}\text { 'Abnormally' high repair rates } \\
\text { in DS children pre- } \\
\text { supplementation was } \\
\text { returned to normal by Zn } \\
\text { supplementation. No effect } \\
\text { of supplementation in } \\
\text { control group }\end{array}$ \\
\hline $\begin{array}{l}\text { Basten et al. } \\
\quad(2006)\end{array}$ & $\begin{array}{l}\text { Blinded placebo-controlled } \\
\text { intervention in human subjects } \\
\text { supplemented with } 1 \cdot 2 \mathrm{mg} \text { folic } \\
\text { acid or a placebo daily for } \\
6 \text { weeks }\end{array}$ & $\begin{array}{l}\text { BER capacity using a } \\
\text { modified comet assay }\end{array}$ & $\begin{array}{l}\text { Sixty-one healthy } \\
\text { subjects (20-60 } \\
\text { years), thirty } \\
\text { supplemented, thirty- } \\
\text { one placebo control }\end{array}$ & $\begin{array}{l}\text { No effect of folic acid on BER } \\
\text { activity }\end{array}$ \\
\hline $\begin{array}{l}\text { Wei et al. } \\
\text { (2003) }\end{array}$ & $\begin{array}{l}\text { Retrospective observational } \\
\text { study. Assessed dietary folate } \\
\text { intake using FFQ }\end{array}$ & $\begin{array}{l}\text { NER capacity using HCR } \\
\text { assay }\end{array}$ & $\begin{array}{l}559 \text { individuals with no } \\
\text { malignancies, (mean } \\
\text { age } 61 \text { years) }\end{array}$ & $\begin{array}{l}18 \% \text { reduction }(P<0.01) \text { in } \\
\text { repair capacity in those in } \\
\text { the lowest tertile of folate } \\
\text { intake compared with those } \\
\text { in the highest tertile }\end{array}$ \\
\hline $\begin{array}{l}\text { Gonzalez et al. } \\
\text { (2002) }\end{array}$ & $\begin{array}{l}\text { Observational study of Mexican } \\
\text { children. Three groups studied: } \\
\text { (1) well-nourished non-infected; } \\
\text { (2) well-nourished infected; } \\
\text { (3) malnourished infected }\end{array}$ & $\begin{array}{l}\text { Followed repair of } \mathrm{H}_{2} \mathrm{O}_{2}- \\
\text { induced DNA damage } \\
\text { over time using the } \\
\text { comet assay }\end{array}$ & $\begin{array}{l}\text { Nineteen children aged } \\
6-26 \text { months }\end{array}$ & $\begin{array}{l}\text { The malnourished infected } \\
\text { children had a significantly } \\
(P<0 \cdot 05) \text { lower repair } \\
\text { capacity than the other two } \\
\text { treatment groups }\end{array}$ \\
\hline
\end{tabular}

OGG1, 8-oxoguanine DNA glycosylase 1; ERCC1, excision repair cross-complementing rodent repair deficiency complementation group 1; BER, base excision repair; $A P E 1$, human apurinic endonuclease 1; NER, nucleotide excision repair; HCR, host cell reactivation. 


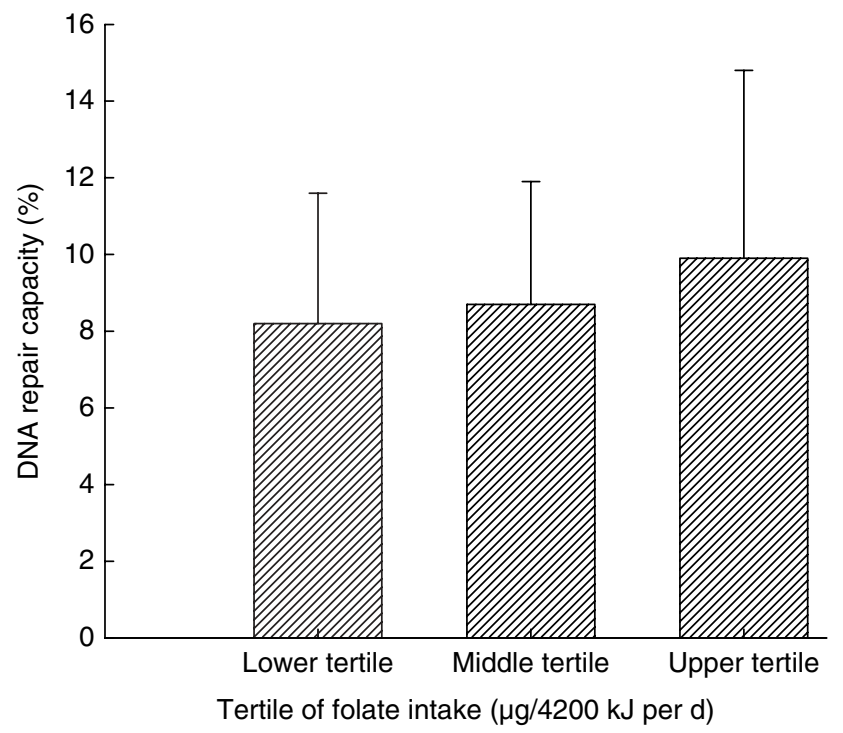

Fig. 3. Association between low dietary folate and DNA repair capacity (Wei et al. 2003). DNA repair capacity was measured using the host cell reactivation assay in 559 healthy individuals. Values are means with their standard errors represented by vertical bars. DNA repair capacity in the lowest tertile of folate intake was significantly lower than that in the highest tertile of folate intake $(P<0.01)$.

surprisingly, malnourished Mexican children carrying an infection have been found to have a lower capacity for repair of oxidative DNA damage when compared with uninfected well-nourished children (Gonzalez et al. 2002). Such findings indicate that undernutrition and associated ill health may impair the capacity for DNA repair, but they are not able to identify which factors, dietary or otherwise, are responsible. However, supplementation of healthy human volunteers with carrot extract increases repair of an $\mathrm{H}_{2} \mathrm{O}_{2}$-damaged plasmid DNA (Astley et al. 2004). Interestingly, supplementation with amounts of $\alpha-(3.7 \mathrm{mg})$ and $\beta-(8.2 \mathrm{mg})$ carotene equivalent to that in the carrot extract have no effect on repair capacity. In the same study separate supplements of $298 \mathrm{~g}$ tinned mandarin oranges or $60 \mathrm{mg}$ vitamin $\mathrm{C}$ were found to have no effect on repair capacity. In a further study (Collins et al. 2003) BER capacity, as measured using a modified comet assay, was found to be increased after supplementation of healthy human volunteers with one, two or three kiwi fruit per d, but there was no evidence of a dose-response relationship. Similarly, supplementation with the antioxidant ubiquinone-10 enhances BER activity in human subjects (Tomasetti et al. 2001). In a cohort of 559 healthy individuals those in the lowest tertile of folate intake were reported (Wei et al. 2003) to have an $18 \%$ reduction in NER capacity compared with those in the highest tertile of intake (see Fig. 3). A significant $(P<0 \cdot 001)$ inverse association was found between total dietary folate intake (adjusted for total energy intake) and repair capacity in non-users of supplemental folate. These findings are supported by in vitro experiments that have shown that folate depletion decreases the repair of peroxide-induced damage in human lymphocytes (Duthie
\& Hawdon, 1998). In contrast, a recent placebo-controlled intervention study (Basten et al. 2006) has found no evidence that supplementation of healthy volunteers with $1.2 \mathrm{mg}$ folic acid/d for 6 weeks affects BER activity (measured using a modified comet assay). However, the failure of the study to detect effects of supplementation does not prove that enhanced folate status is without effect on DNA repair capacity. The intervention study was of modest size (thirty subjects receiving supplement and thirty-one controls) and would therefore be able to detect only relatively large changes in repair. There was also a suggestion that those subjects with the lowest folate status initially showed a decrease in repair in response to supplementation (Basten et al. 2006). Additionally, it remains to be determined whether the dose of folic acid, which is well above the UK reference nutrient intake of $200 \mu \mathrm{g} / \mathrm{d}$ (Department of Health, 2002), is necessary to support optimal DNA repair.

\section{Mechanisms through which diet may modulate DNA repair processes}

As there has been limited research into the dietary modulation of DNA repair, there is little direct evidence for biological mechanisms through which DNA repair processes may be modified by diet. However, a number of possible mechanisms can be, and have been, proposed based on previous observations and knowledge of how diet can affect other cellular processes. Diet may modify DNA repair through changes at the level of transcription, although effects on mRNA stability translation, protein stability and protein trafficking should also be considered. Candidate mechanisms through which nutrients and other dietary components may influence gene expression have been reviewed recently (Mathers, 2006). The availability of any nutrient necessary for the proficient synthesis of DNA, RNA and proteins may impact on DNA repair processes. This factor may explain the decreased BER capacity of malnourished children reported by Gonzalez et al. (2002), although as yet there is no direct mechanistic evidence.

Some of the most convincing indirect mechanistic evidence in this area comes from in vitro work with Se, which (in the form of selenomethionine) increases NER capacity 2-fold in human fibroblast cells (Seo et al. 2002b). Followup work (Seo et al. 2002a) has found that this Se-induced increase in repair is dependent on both P53 and the protein redox factor-1, with Se reducing specific cytosine residues on P53. Furthermore, this Se-dependent reduction of P53 is lost in cells lacking redox factor-1, suggesting that redox factor-1 is an intermediary in the Se-dependent activation of P53. It has now been demonstrated (Fischer et al. 2006) that Se-induced activation of P53 is also dependent on the presence of the BRCA1 protein, which is believed to be important in recombinational repair and is frequently mutated in heritable breast cancer.

A further mechanism through which Se may influence DNA repair is through alterations to the binding activity of transcription factors and DNA repair proteins. Using mobility shift assays in an extracellular system it has been 
shown (Handel et al. 1995) that $\mathrm{Na}_{2} \mathrm{SeO}_{3}(1 \mu \mathrm{M})$ inhibits binding of the transcription factor activator protein-1 to its consensus DNA sequence by $50 \%$. Similar effects on consensus sequence binding of NF- $\mathrm{\kappa B}$, as well as transcription factors SP-1 and SP-3, have been reported (Youn et al. 2001). More specifically, reducible Se compounds inhibit the NER protein XPA and the BER protein formamidopyrimidine DNA glycosylase, both of which belong to a family of DNA-binding proteins (Blessing et al. 2004), known as $\mathrm{Zn}$ finger proteins, in which $\mathrm{Zn}$ atoms are complexed with cysteine and/or histidine residues, forming domains through which the protein can bind DNA. Reducible Se compounds lower the removal of oxidative damage by the formamidopyrimidine DNA glycosylase enzyme and binding of the XPA protein in a dosedependent manner (Blessing et al. 2004). $\mathrm{Zn}$ atoms are released from both XPA and formamidopyrimidine DNA glycosylase on Se treatment, suggesting that the displacement of $\mathrm{Zn}$ from $\mathrm{Zn}$ fingers results in inactivation of the protein. Approximately $3 \%$ of all proteins contain $\mathrm{Zn}$ finger motifs, including P53 and several other important DNA repair proteins. Thus, disruption to their functional domains could exert wide-ranging effects on DNA repair and other cellular processes. The intake and bioavailability of $\mathrm{Zn}$ itself may be of importance, since adequate $\mathrm{Zn}$ status is required for optimal functioning of these proteins (Ho, 2004).

An additional important mechanism through which diet may influence DNA repair is via hypermethylation of $\mathrm{CpG}$ islands (short stretches of DNA with a higher frequency of the CG sequence) in the promoter regions of repair genes, leading to gene silencing. The $\mathrm{O}^{6}$-methylguanineDNA methyltransferase (which repairs alkylated guanine bases; Nakagawachi et al. 2003) and MLHI (a key component of mismatch repair; Feinberg \& Tycko, 2004) genes are both silenced by promoter hypermethylation during tumourigenesis. Folate may alter DNA methylation via its role as a methyl donor and thus influence the expression of key DNA repair genes. Other dietary factors, including Zn, Se and vitamin C, may also alter DNA methylation (Friso \& Choi, 2002).

Given its apparent benefit in extending longevity in rodents and some other animals, it is interesting to note the effects of energy restriction on DNA repair capacity, which to date has been investigated in four animal studies (Guo et al. 1998; Cabelof et al. 2003; Stuart et al. 2004; Gedik et al. 2005). Rats fed an energy-restriction diet do not show the age-related decline in either BER (Cabelof et al. 2003) or NER (Guo et al. 1998) seen in rats fed an unrestricted diet. A third study (Gedik et al. 2005) has found that energy restriction has no effect on the repair of peroxide-induced strand breaks in ageing rats. However, in the latter study the aged rats were sampled at 17 months as compared with 24 months in the first two studies. Furthermore, DNA repair was quantified by inducing strand breaks, not by following the repair of DNA adducts as in the previous two studies. A fourth study (Stuart et al. 2004) has found that the activity of specific BER enzymes in liver, but not kidney, tissue increases in mice fed an energy-restriction diet. Here, the effects of ageing were not considered, and it is yet to be established whether energy restriction can enhance DNA repair or simply prevent its age-related decline. The results of the Stuart et al. (2004) study also suggest that tissue-specific differences in repair should be considered in future observational and intervention studies.

One of the most obvious ways in which energy restriction could affect DNA repair is through altered gene expression. Animal studies have shown that energy restriction alters the expression of numerous genes, including those involved in DNA repair pathways (Lee et al. 1999; Weindruch et al. 2001). Energy restriction is known to reduce the production of harmful oxygen species, and it may also alter protein synthesis and immune function (Dirx et al. 2003). It is possible that one or more of these effects may contribute to the changes in DNA repair associated with reduced energy intake. Increased DNA repair capacity could contribute to the increased lifespan and reduced age-associated changes seen in organisms in which energy intake is restricted.

\section{Concluding remarks}

DNA damage if unrepaired leads to aberrant gene expression, which is fundamental to the initiation and progression of many diseases. Much research aimed at understanding the beneficial health effects of diet and dietary components has focused on DNA damage. However, DNA damage is only of consequence if left unrepaired. It is clear that interindividual variation in DNA repair capacity in apparentlyhealthy populations is high and that there may be important implications for disease risk if the capacity for DNA repair is suboptimal. This inter-individual variation in DNA repair capacity is explained in part by polymorphisms in the genes that encode DNA repair proteins. However, to date it has not been shown that any single polymorphism can account consistently for variations in DNA repair capacity, and future studies should utilise high-throughput genomic technologies to assess the effects of multiple polymorphisms on repair capacity.

Although only a limited number of studies have investigated the effects of diet and dietary factors on DNA repair processes, the results support the hypothesis that nutrition may have an important influence on DNA repair. There is some evidence that whole diet and specific dietary components and nutrients can modify DNA repair processes. However, further investigations will be required to determine which components of the diet affect DNA repair and to establish intake levels that optimise repair capacity.

As with several other areas of human physiology, interactions between environmental exposure, especially dietary exposure, and genetic make up will be an important area of investigation. Future studies should address the hypothesis that dietary exposure may have different effects on health depending on the genetic background of the individual. Progress in this area will be helped by the development of high-throughput technologies for quantifying DNA repair capacity and by more objective and less-labour-intensive methods for assessing dietary exposure. 


\section{Acknowledgments}

We acknowledge collaboration by the Dietary Antioxidant Repair Trial team, including John Hesketh, Fiona Caple, Alison Spiers, Ann Daly and Elizabeth Williams, and funding from the BBSRC (project no. 13/D15721). J.T. is funded by a BBSRC studentship (02/B1/D/08297).

\section{References}

Ana S, Neumann EMS \& Wei Q (2005) Nucleotide excision repair as a marker for susceptibility to tobacco-related cancers: A review of molecular epidemiological studies. Molecular Carcinogenesis 42, 65-92.

Astley SB, Elliott RM, Archer DB \& Southon S (2004) Evidence that dietary supplementation with carotenoids and carotenoidrich foods modulates the DNA damage: repair balance in human lymphocytes. British Journal of Nutrition 91, 63-72.

Basten GP, Duthie SJ, Pirie L, Vaughan N, Hill MH \& Powers HJ (2006) Sensitivity of markers of DNA stability and DNA repair activity to folate supplementation in healthy volunteers. British Journal of Cancer 94, 1942-1947.

Benhamou S \& Sarasin A (2000) Variability in nucleotide excision repair and cancer risk: a review. Mutation Research 462, 149-158.

Benhamou S \& Sarasin A (2005) ERCC2/XPD gene polymorphisms and lung cancer: A HuGE review. American Journal of Epidemiology 161, 1-14.

Berwick M \& Vineis P (2000) Markers of DNA repair and susceptibility to cancer in humans: an epidemiologic review. Journal of the National Cancer Institute 92, 874-897.

Bingham SA, Day NE, Luben R, Ferrari P, Slimani N, Norat T et al. (2003) Dietary fibre in food and protection against colorectal cancer in the European Prospective Investigation into Cancer and Nutrition (EPIC): an observational study. Lancet 361, 1496-1501.

Blessing H, Kraus S, Heindl P, Bal W \& Hartwig A (2004) Interaction of selenium compounds with zinc finger proteins involved in DNA repair. European Journal of Biochemistry 271, 3190-3199.

Cabelof DC, Yanamadala S, Raffoul JJ, Guo Z, Soofi A \& Heydari AR (2003) Caloric restriction promotes genomic stability by induction of base excision repair and reversal of its age-related decline. DNA Repair (Amst) 2, 295-307.

Chiricolo M, Musa AR, Monti D, Zannotti M \& Franceschi C (1993) Enhanced DNA repair in lymphocytes of Down syndrome patients: the influence of zinc nutritional supplementation. Mutation Research 295, 105-111.

Christmann M, Tomicic MT, Roos WP \& Kaina B (2003) Mechanisms of human DNA repair: an update. Toxicology 193, 3-34.

Collins AR, Harrington V, Drew J \& Melvin R (2003) Nutritional modulation of DNA repair in a human intervention study. Carcinogenesis 24, 511-515.

de Boer J \& Hoeijmakers JH (2000) Nucleotide excision repair and human syndromes. Carcinogenesis 21, 453-460.

de Laat WL, Jaspers NG \& Hoeijmakers JH (1999) Molecular mechanism of nucleotide excision repair. Genes and Development 13, 768-785.

Department of Health (2002) Folic Acid and the Prevention of Disease. Report on Health and Social Subjects no. 50. London: The Stationery Office.

Dirx MJ, Zeegers MP, Dagnelie PC, van den Bogaard T \& van den Brandt PA (2003) Energy restriction and the risk of spontaneous mammary tumors in mice: a meta-analysis. International Journal of Cancer 106, 766-770.
Doll R \& Peto R (1981) The causes of cancer: quantitative estimates of avoidable risks of cancer in the United States today. Journal of the National Cancer Institute 66, 11911308.

Duell EJ, Wiencke JK, Cheng TJ, Varkonyi A, Zuo ZF, Ashok TD, Mark EJ, Wain JC, Christiani DC \& Kelsey KT (2000) Polymorphisms in the DNA repair genes XRCC1 and ERCC2 and biomarkers of DNA damage in human blood mononuclear cells. Carcinogenesis 21, 965-971.

Duthie SJ \& Hawdon A (1998) DNA instability (strand breakage, uracil misincorporation, and defective repair) is increased by folic acid depletion in human lymphocytes in vitro. FASEB Journal 12, 1491-1497.

Feinberg AP \& Tycko B (2004) The history of cancer epigenetics. Nature Reviews Cancer 4, 143-153.

Fischer JL, Lancia JK, Mathur A \& Smith ML (2006) Selenium protection from DNA damage involves a Ref1/p53/Brca1 protein complex. Anticancer Research 26, 899-904.

Friedberg EC (2001) How nucleotide excision repair protects against cancer. Nature Reviews Cancer 1, 22-33.

Friso S \& Choi S-W (2002) Gene-nutrient interactions and DNA methylation. Anticancer Research 132, 2382S-2387S.

Gedik CM, Grant G, Morrice PC, Wood SG \& Collins AR (2005) Effects of age and dietary restriction on oxidative DNA damage, antioxidant protection and DNA repair in rats. European Journal of Nutrition 44, 263-272.

Gonzalez C, Najera O, Cortes E, Toledo G, Lopez L, Betancourt M \& Ortiz R (2002) Hydrogen peroxide-induced DNA damage and DNA repair in lymphocytes from malnourished children. Environmental and Molecular Mutagenesis 39, 33-42.

Guo Z, Heydari A \& Richardson A (1998) Nucleotide excision repair of actively transcribed versus nontranscribed DNA in rat hepatocytes: effect of age and dietary restriction. Experimental Cell Research 245, 228-238.

Handel M, Watts C, DeFazio A, Day R \& Sutherland R (1995) Inhibition of AP-1 binding and transcription by gold and selenium involving conserved cysteine residues in Jun and Fos. Proceedings of the National Academy of Sciences USA 92, 4497-4501.

Ho E (2004) Zinc deficiency DNA damage and cancer risk. Journal of Nutritional Biochemistry 15, 572-578.

Hou SM, Falt S, Angelini S, Yang K, Nyberg F, Lambert B \& Hemminki K (2002) The XPD variant alleles are associated with increased aromatic DNA adduct level and lung cancer risk. Carcinogenesis 23, 599-603.

Hung RJ, Hall J, Brennan P \& Boffetta P (2005) Genetic polymorphisms in the base excision repair pathway and cancer risk: A HuGE review. American Journal of Epidemiology 162, 925-942.

Jackson AL \& Loeb LA (2001) The contribution of endogenous sources of DNA damage to the multiple mutations in cancer. Mutation Research 477, 7-21.

Jiricny J \& Nystrom-Lahti M (2000) Mismatch repair defects in cancer. Current Opinion in Genetics and Development 10 , 157-161.

Lee CK, Klopp RG, Weindruch R \& Prolla TA (1999) Gene expression profile of aging and its retardation by caloric restriction. Science 285, 1390-1393.

Mathers JC (2006) Candidate mechanisms for interactions between nutrients and genes. In Nutrient-Gene Interactions in Cancer, pp. 19-36 [S-W Choi and S Friso, editors]. Boca Raton, USA: Taylor \& Francis Group.

Mohankumar MN, Paul SF, Venkatachalam P \& Jeevanram RK (1998) Influence of in vitro low-level gamma-radiation on the UV-induced DNA repair capacity of human lymphocytes analysed by unscheduled DNA synthesis (UDS) and comet assay. Radiation and Environmental Biophysics 37, 267-275. 
Mohrenweiser HW, Xi T, Vazquez-Matias J \& Jones IM (2002) Identification of 127 amino acid substitution variants in screening 37 DNA repair genes in humans. Cancer Epidemiology, Biomarkers and Prevention 11, 1054-1064.

Moller P \& Loft S (2004) Interventions with antioxidants and nutrients in relation to oxidative DNA damage and repair. Mutation Research 551, 79-89.

Moller P, Vogel U, Pedersen A, Dragsted LO, Sandstrom B \& Loft S (2003) No effect of 600 grams fruit and vegetables per day on oxidative DNA damage and repair in healthy nonsmokers. Cancer Epidemiology, Biomarkers and Prevention 12, 1016-1022.

Nakagawachi T, Soejima H, Urano T, Zhao W, Higashimoto K, Satoh Y et al. (2003) Silencing effect of CpG island hypermethylation and histone modifications on O6-methylguanineDNA methyltransferase (MGMT) gene expression in human cancer. Oncogene 22, 8835-8844.

Norat T, Bingham S, Ferrari P, Slimani N, Jenab M, Mazuir M et al. (2005) Meat, fish, and colorectal cancer risk: the European Prospective Investigation into Cancer and Nutrition. Journal of the National Cancer Institute 97, 906-916.

Pachkowski BF, Winkel S, Kubota Y, Swenberg JA, Millikan RC \& Nakamura J (2006) XRCC1 genotype and breast cancer: functional studies and epidemiologic data show interactions between XRCC1 codon 280 His and smoking. Cancer Research 66, 2860-2868.

Palli D, Russo A, Masala G, Saieva C, Guarrera S, Carturan S, Munnia A, Matullo G \& Peluso M (2001) DNA adduct levels and DNA repair polymorphisms in traffic-exposed workers and a general population sample. International Journal of Cancer 94, 121-127.

Paz-Elizur T, Krupsky M, Blumenstein S, Elinger D, Schechtman E \& Livneh Z (2003) DNA repair activity for oxidative damage and risk of lung cancer. Journal of the National Cancer Institute 95, 1312-1319.

Pfeiffer P, Goedecke W \& Obe G (2000) Mechanisms of DNA double-strand break repair and their potential to induce chromosomal aberrations. Mutagenesis 15, 289-302.

Qiao Y, Spitz MR, Guo Z, Hadeyati M, Grossman L, Kraemer KH \& Wei Q (2002a) Rapid assessment of repair of ultraviolet DNA damage with a modified host-cell reactivation assay using a luciferase reporter gene and correlation with polymorphisms of DNA repair genes in normal human lymphocytes. Mutation Research 509, 165-174.

Qiao Y, Spitz MR, Shen H, Guo Z, Shete S, Hedayati M, Grossman L, Mohrenweiser H \& Wei Q (2002b) Modulation of repair of ultraviolet damage in the host-cell reactivation assay by polymorphic XPC and XPD/ERCC2 genotypes. Carcinogenesis 23, 295-299.

Ralhan R, Kaur J, Kreienberg R \& Wiesmuller L (2006) Links between DNA double strand break repair and breast cancer: Accumulating evidence from both familial and nonfamilial cases. Cancer Letters (In the Press).

Seeberg E, Eide L \& Bjoras M (1995) The base excision repair pathway. Trends in Biochemical Sciences 20, 391-397.
Seo YR, Kelley MR \& Smith ML (2002a) Selenomethionine regulation of $\mathrm{p} 53$ by a ref1-dependent redox mechanism. Proceedings of the National Academy of Sciences USA 99, 14548-14553.

Seo YR, Sweeney C \& Smith ML (2002b) Selenomethionine induction of DNA repair response in human fibroblasts. Oncogene 21, 3663-3669.

Sheng Y, Pero RW, Olsson AR, Bryngelsson C \& Hua J (1998) DNA repair enhancement by a combined supplement of carotenoids, nicotinamide, and zinc. Cancer Detection and Prevention 22, 284-292.

Sokhansanj BA \& Wilson DM 3rd (2006) Estimating the effect of human base excision repair protein variants on the repair of oxidative DNA base damage. Cancer Epidemiology, Biomarkers and Prevention 15, 1000-1008.

Spitz MR, Wu X, Wang Y, Wang LE, Shete S, Amos CI, Guo Z, Lei L, Mohrenweiser H \& Wei Q (2001) Modulation of nucleotide excision repair capacity by XPD polymorphisms in lung cancer patients. Cancer Research 61, 1354-1357.

Stuart JA, Karahalil B, Hogue BA, Souza-Pinto NC \& Bohr VA (2004) Mitochondrial and nuclear DNA base excision repair are affected differently by caloric restriction. FASEB Journal 18, 595-597.

Tang D, Cho S, Rundle A, Chen S, Phillips D, Zhou J, Hsu Y, Schnabel F, Estabrook A \& Perera FP (2002) Polymorphisms in the DNA repair enzyme XPD are associated with increased levels of PAH-DNA adducts in a case-control study of breast cancer. Breast Cancer Research and Treatment 75, 159-166.

Tomasetti M, Alleva R, Borghi B \& Collins AR (2001) In vivo supplementation with coenzyme Q10 enhances the recovery of human lymphocytes from oxidative DNA damage. FASEB Journal 15, 1425-1427.

Tyson J, Spiers A, Caple F, Hesketh JE \& Mathers JC (2005) Inter-individual variation in nucleotide excision repair capacity: potential scope for dietary modulation of DNA repair. Proceedings of the Nutrition Society 64, 68A.

Tyson J, Spiers A, Caple F, Hesketh JE \& Mathers JC (2006) Effects of age, BMI and genotype on nucleotide excision repair in healthy adults. Proceedings of the Nutrition Society 65, 114A.

Wei Q, Shen H, Wang LE, Duphorne CM, Pillow PC, Guo Z, Qiao Y \& Spitz MR (2003) Association between low dietary folate intake and suboptimal cellular DNA repair capacity. Cancer Epidemiology, Biomarkers and Prevention 12, 963-939.

Weindruch R, Kayo T, Lee C-K \& Prolla TA (2001) Microarray profiling of gene expression in aging and its alteration by caloric restriction in mice. Journal of Nutrition 131, 918S923S.

World Cancer Research Fund/American Institute for Cancer Research (1997) Food, Nutrition and the Prevention of Cancer: A Global Perspective. London: WCRF UK.

Youn BW, Fiala ES \& Sohn OS (2001) Mechanisms of organoselenium compounds in chemoprevention: effects on transcription factor-DNA binding. Nutrition and Cancer 40, 28-33. 